\title{
The effect of using soyabean or linseed oil with RRR-d- $\alpha$-tocopherol or dl- $\alpha$-tocopherol acetate on haematological parameters and rearing performance of young turkey hens
}

\author{
A. Czech $^{1}$ and K. Ognik \\ University of Life Sciences in Lublin, Department of Biochemistry and Toxicology, Akademicka 13, 20-950 Lublin, Poland
}

KEY WORDS: turkey hen, soyabean oil, linseed oil, tocopherol, performance, blood

Received: 12 November 2013

Revised: 25 August 2014

Accepted: 10 September 2014

${ }^{1}$ Corresponding author:

e-mail: annaczech@poczta.fm

\begin{abstract}
The aim of the study was to analyse whether and to what degree the use of RRR-d-a-tocopherol in diets containing an oil rich in linoleic or linolenic acid (soyabean or linseed oil, respectively) would make it possible to halve the dosage of this antioxidant with respect to that of a-tocopherol without negatively affecting the metabolic status and rearing performance of slaughter turkey hens. A study was performed on 480 one-week-old turkey hens reared until the $16^{\text {th }}$ week of life. The hens in groups I and II received soyabean oil, in groups III and IV linseed oil in feed mixture. The birds in groups I and III received dl-a-tocopherol acetate, whereas those in groups II and IV RRR-d-a-tocopherol. The body weight gain and feed intake were monitored. Selected haematological and biochemical parameters were estimated in blood. The linseed oil was found to improve production effects and carcass traits in turkey hens. It may also contribute to stimulation of erythropoiesis. It should be emphasized, however, that it may overburden the organism, as indicated by the increased activity of liver enzymes. It is possible to use the natural form of tocopherol in diets rich in linoleic and linolenic acid (soyabean/linseed oil) without detrimental effect on metabolic status and rearing performance in turkey hens. Nonetheless, the commonly used tocopherol acetate, despite the higher dosage, is cheaper and has similar effects. Thus, from an economic point of view, the use of linseed oil with the synthetic form of vitamin $E$ can be recommended.
\end{abstract}

\section{Introduction}

The search for new feed additives or feed components for poultry is aimed primarily at improving the effectiveness of feed mixtures, rearing performance and the health status of birds. The main source of fat in turkey diets is usually soyabean oil, which is rich in $\omega-6$ polyunsaturated fatty acids (PUFA) - 53.2\% linoleic acid (LA), and contains the following percentages of fatty acids: $15 \%$ saturated fatty acids (SFA), 26\% monounsaturated fatty acids (MUFA) and 59\% PUFA. The use of linseed oil, however, shows great promise. It is rich in $\omega-3$ PUFA - 58\% linolenic acid (LNA), and contains the following fatty acids: 9\% SFA, 19\% MUFA and $72 \%$ PUFA (Hassan et al., 2011). The use of linseed oil as a source of polyunsaturated fatty acids seems especially interesting. Supplying PUFA in the diet 
seems to be particularly advisable because the composition of dietary fatty acids is reflected in the fatty acid composition of the cellular membrane of lymphocytes and other cells of the immune system. This, in turn, exerts a direct effect on their functioning, particularly on their ability to produce certain transmitter molecules, e.g., prostaglandins and interleukins, while PUFA also indirectly regulate metabolic processes in the body (Hassan et al., 2011).

Apart from polyunsaturated fatty acids, oil - particularly linseed oil - is also a source of antioxidants (Kania et al., 2004; Kouba and Mourot, 2011). They occur in small quantities, however, and because linseed oil is highly susceptible to oxidation, it is very important to protect it by adding antioxidants. An antioxidant commonly used in livestock feeding is synthetic dl- $\alpha$-tocopherol (Yu et al., 2008). It is not very stable so, in practice, it is applied in the form of acetate as a component of preparations designed to supplement animal diets with vitamin E (Koreleski and Świątkiewicz, 2008). Currently, feed additives in poultry diets include several precursor forms of tocopherol that are active in cells (systemic), but whose biological activity varies substantially depending on the isomeric structure, such as RRRRRS-RSR-RSS (the isomers are available systemically from $50 \%$ up to $100 \%$ ) or SRR-SSR-SRS-SSS (inactive systemically) and on the chemical form of the compound. For example, the conformers RRR $+\mathrm{RRS}+\mathrm{RSR}+\mathrm{SRR}$ in dl- $\alpha$-tocopherol acetate activity equivalents of $62.5 \mathrm{~g}-\mathrm{RRR} \times$ active are as follows:

$1(100)=62.5 \mathrm{~g}$ of vitamin E $62.5 \mathrm{~g}-\mathrm{RSR} \times$ active,

$0.57=35.6 \mathrm{~g}$ of vitamin $\mathrm{E} 62.5 \mathrm{~g}-\mathrm{RRS} \times$ active,

$0.9=56.3 \mathrm{~g}$ of vitamin E $62.5 \mathrm{~g}-\mathrm{RSS} \times$ active, and $0.73=45.6 \mathrm{~g}$ of vitamin $\mathrm{E}$,

which produced $200 \mathrm{~g}$ of vitamin E active in $1000 \mathrm{~g}$ of acetate as a product (Cortinas et al., 2004). According to Koreleski and Świątkiewicz (2008), the activity of the RRR-stereoisomer [2,5,7,8-tetramethyl-2R-(4.R, 8.R, 12-trimethyltridecyl) 6-chromonol] is nearly two times higher than that of the synthetic form of vitamin E, which suggests that it can be used in mixtures for turkey hens in half the amount recommended by the NRC (1994). This has been confirmed by research, including our own, Ognik and Czech (2014), which showed that addition of the natural form of RRR-d- $\alpha$-tocopherol to both soyabean and linseed oils stimulated antioxidant defence mechanisms (reduction in CAT, increased GSH and selenium) more effectively than dl-alpha-tocopherol acetate added to these oils.

The aim of the study was to analyse whether and to what degree the use of RRR-d- $\alpha$-tocopherol in diets containing oil rich in linoleic or linolenic acid (soyabean or linseed oil, respectively) would make it possible to halve the dosage of this antioxidant with respect to that of $\alpha$-tocopherol without negatively affecting the metabolic status and rearing performance of slaughter turkey hens.

\section{Material and methods}

\section{Animals and diets}

The experiment was carried out on 480 turkey hens of the Big 6 line, aged from 7 to 16 weeks. The birds were randomly assigned to 4 experimental groups of 120 turkeys, with 5 replications of 24 birds each. The birds were kept in cages $2.5 \mathrm{~m} \times 4 \mathrm{~m}$ in size, under conditions recommended for turkey fattening. The turkey hens in groups I and II received soyabean oil added to their feed mixture. The source of fat for groups III and IV was linseed oil. Group I and III received synthetic dl- $\alpha$-tocopherol acetate (dl$\alpha$-tocopherol acetate $-\mathrm{E} 307$, according to EC $1831 / 2003)$ at dietary levels of $50 \mathrm{mg} \cdot \mathrm{kg}^{-1}(1-9$ wk of life) and $45 \mathrm{mg} \cdot \mathrm{kg}^{-1}$ (10-16 wk of life), which was consistent with the tocopherol content recommended for turkey hens by the NRC (1994). Groups II and IV were given another form of tocopherol, i.e. natural RRR-d- $\alpha$-tocopherol available on the commercial market (an extract of soyabean oil as a powder) at a rate 2 times lower than in groups I and III, i.e. $25 \mathrm{mg} \cdot \mathrm{kg}^{-1}$ (1-9 wk of life) and $22.5 \mathrm{mg} \cdot \mathrm{kg}^{-1}(10-16 \mathrm{wk}$ of life). All of the mixtures were isonitrogenous and isoenergetic (Table 1). The base mixture was introduced into the premix (vitamin and mineral supplement; Table 1). The halved dosage was in accordance with research by Mahan et al. (2000), who suggest that the activity of the natural form of vitamin $\mathrm{E}$ in animal tissues is significantly higher than the synthetic form.

The turkey hens from all the groups were fed ad libitum and had free access to water. The feed mixtures were prepared once a week at the farm and were kept in a cool and dark place to prevent oxidation. During the experiment the turkey hens' body weight (taken on the last day of each week of the experiment), survival rate and feed intake were recorded. The Production Number (PN) was calculated on the basis of productive performance according to the formula given by Euribrid (1994):

$\mathrm{PN}=$ average liveweight $\times \%$ survivability/days (duration of fattening) $\times$ FCR : 10 
Table 1. Composition and nutrients of basal diets for turkey hens

\begin{tabular}{|c|c|c|c|c|c|}
\hline Indices & $\begin{array}{l}\text { Starter } \\
\text { (1-2 wk of age) }\end{array}$ & $\begin{array}{l}\text { Grower I } \\
\text { (3-5 wk of age) }\end{array}$ & $\begin{array}{l}\text { Grower II } \\
\text { (6-9 wk of age) }\end{array}$ & $\begin{array}{l}\text { Grower III } \\
(10-12 \text { wk of age) }\end{array}$ & $\begin{array}{l}\text { Finisher I } \\
\text { (13-16 wk of age) }\end{array}$ \\
\hline \multicolumn{6}{|l|}{ Ingredient, in $1 \mathrm{~kg}$ of mixture } \\
\hline maize meal, g & 256 & 274 & 238 & 352 & 474 \\
\hline wheat, $g$ & 200 & 250 & 300 & 250 & 250 \\
\hline wheat bran, $g$ & 30 & - & - & - & - \\
\hline soyabean meal g & 430 & 417 & 388 & 327 & 204 \\
\hline fish meal $60 \%, g$ & 35 & - & - & - & - \\
\hline fodder chalk, $g$ & 12 & 17 & 17 & 14 & 15 \\
\hline soyabean oil or linseed oil, g & 5 & 10 & 25 & 30 & 30 \\
\hline Cytromix Plus ${ }^{1}, g$ & 2 & 2 & 2 & 2 & 2 \\
\hline Premix, g & 30 & 30 & 30 & 25 & 25 \\
\hline \multicolumn{6}{|l|}{ Nutritive value, in $1 \mathrm{~kg}$ of mixture } \\
\hline crude protein, $g$ & 271 & 255 & 245 & 220 & 175 \\
\hline crude fibre, $g$ & 28.6 & 27.7 & 27.2 & 27.1 & 27.0 \\
\hline lysine, $\mathrm{g}$ & 16.1 & 15.5 & 13.8 & 11.9 & 10.1 \\
\hline methionine + cysteine, $\mathrm{g}$ & 9.8 & 9.0 & 8.8 & 7.9 & 7.0 \\
\hline tryptophan, g & 3.4 & 2.8 & 2.7 & 2.3 & 1.9 \\
\hline arginine, $g$ & 17.7 & 15.7 & 15.0 & 13.2 & 9.8 \\
\hline $\mathrm{Ca}, \mathrm{g}$ & 13.9 & 12.3 & 11.7 & 10.6 & 9.4 \\
\hline$P$ available, $g$ & 7.7 & 6.7 & 5.9 & 5.7 & 4.7 \\
\hline $\mathrm{Na}, \mathrm{g}$ & 1.5 & 1.6 & 1.5 & 1.5 & 1.5 \\
\hline ME, MJ & 11.45 & 11.73 & 12.19 & 12.58 & 13.09 \\
\hline \multicolumn{6}{|c|}{ Composition of mineral and vitamin premixes, in $1 \mathrm{~kg}$ of mixture } \\
\hline vitamin $A$, IU & 15000.0 & 13000.0 & 13000.0 & 10416.7 & 11250.0 \\
\hline vitamin $D_{3}$, IU & 5000.0 & 4000.0 & 4000.0 & 3125.0 & 3400.0 \\
\hline vitamin E (dl-a-tocopherol acetate) $)^{2}, \mathrm{mg}$ & 69.99 & 54.99 & 54.99 & 39.58 & 45.00 \\
\hline vitamin $\mathrm{K}_{3}$, mg & 4.00 & 3.00 & 3.00 & 2.50 & 2.25 \\
\hline vitamin $\mathrm{B}_{1}$, mg & 5.00 & 3.48 & 3.48 & 2.08 & 2.25 \\
\hline vitamin $\mathrm{B}_{2}$, mg & 10.09 & 9.00 & 9.00 & 6.65 & 7.50 \\
\hline vitamin $B_{6}, \mathrm{mg}$ & 6.00 & 5.00 & 5.00 & 4.17 & 4.15 \\
\hline vitamin $\mathrm{B}_{12}, \mathrm{mg}$ & 0.03 & 0.03 & 0.03 & 0.02 & 0.02 \\
\hline folic acid, mg & 2.25 & 2.00 & 2.00 & 1.67 & 1.75 \\
\hline biotin, mg & 0.35 & 0.30 & 0.30 & 0.23 & 0.23 \\
\hline nicotinic amide, mg & 75.00 & 64.98 & 64.98 & 52.08 & 50.00 \\
\hline calcium pantothenate, $\mathrm{mg}$ & 22.50 & 18.48 & 18.48 & 14.58 & 15.00 \\
\hline choline, mg & 600.00 & 399.99 & 399.99 & 312.50 & 300.00 \\
\hline $\mathrm{Mn}, \mathrm{mg}$ & 150.00 & 120.00 & 120.00 & 100.00 & 120.00 \\
\hline $\mathrm{Zn}, \mathrm{mg}$ & 99.99 & 90.00 & 90.00 & 75.00 & 80.00 \\
\hline $\mathrm{Fe}, \mathrm{mg}$ & 60.00 & 49.98 & 49.98 & 41.68 & 45.00 \\
\hline $\mathrm{Cu}, \mathrm{mg}$ & 15.00 & 19.98 & 19.98 & 18.75 & 22.50 \\
\hline I, mg & 2.00 & 1.75 & 1.75 & 1.46 & 1.50 \\
\hline Se, mg & 0.30 & 0.30 & 0.30 & 0.25 & 0.30 \\
\hline Co, mg & 0.20 & 0.20 & 0.20 & 0.17 & 0.20 \\
\hline $\mathrm{Ca}, \mathrm{g}$ & 4.80 & 4.05 & 3.99 & 3.75 & 3.60 \\
\hline P total, $g$ & 4.56 & 4.65 & 4.65 & 4.35 & 4.35 \\
\hline $\mathrm{Na}, \mathrm{g}$ & 0.60 & 1.05 & 1.20 & 1.26 & 1.56 \\
\hline lysine, $g$ & 1.80 & 2.70 & 2.55 & 3.00 & 3.00 \\
\hline methionine, $g$ & 1.44 & 1.59 & 1.50 & 1.65 & 1.56 \\
\hline threonine, $g$ & 0.00 & 0.21 & 0.30 & 0.45 & 0.45 \\
\hline coccidiostat-monoenzyne & + & + & + & + & - \\
\hline
\end{tabular}

${ }^{1}$ Cytromix Plus - citric acid, fumaric acid, phosphoric acid (62\%); ${ }^{2}$ in groups II and IV the amount of RRR-d-a-tocopherol was 2 times lower 


\section{Collection of samples and analytical methods}

At the end of week 16, blood samples were collected from the brachial vein of 10 birds from each group (two birds of similar body weight for each replication) in order to determine the haematocrit (Ht) by the microhaematocrit method, haemoglobin content $(\mathrm{Hb})$ by Drabkin's method and erythrocyte count (RBC) manually by the chamber technique, following dilution in Natt-Herrick solution. The haemoglobin concentration was determined by spectrophotometry following lysis of erythrocytes and release of haemoglobin (Feldman et al., 2000).

Test kits developed by Cormay (Lublin, Poland) were used to determine the content of total protein (TP), glucose (GLU), phosphorus, calcium and magnesium. Test kits were also used to determine the activity of selected enzymes: alanine aminotransferase (ALT), aspartate aminotransferase (AST), alkaline phosphatase (AP) and lactate dehydrogenase (LDH). The contents of iron, zinc and copper in blood plasma were determined at the Central Apparatus Laboratory, University of Life Sciences in Lublin, by flame AAS with a UNICAM 939 spectrometer.

On completion of the rearing period (16 weeks of age), ten birds from each experimental group were slaughtered following the euthanasia protocol of the II Local Ethics Commission for Experiments with Animals in Lublin (approval No. 9/2009); all of the birds from a group/subgroup were weighed and then chosen for carcass analysis on the basis of mean body weight. During the partial dissection, breast and leg muscles and edible giblets (liver, heart and gizzard) were sampled.

\section{Statistical analysis}

All data were analysed as a $2 \times 2$ factorial randomized block design with tocopherol level and oil source and their interaction as the main effects, using the general ANOVA procedure of Statistica v. 6.1 software (2003). Results are presented as treatment means and SEM. Significance of differences between mean values was estimated by means of single-factor analysis of variance (ANOVA) assuming significance levels of 0.05 and 0.01 .

\section{Results}

Turkey hens fed the feed mixture with linseed oil had about $8 \%$ higher final body weight $(P \leq 0.05)$. Better feed utilization was also noted in these birds. The effect of adding oil on feed utilization was confirmed statistically. The birds of group III also had higher $(P \leq 0.05)$ production numbers $(\mathrm{PN})$ compared with the other experimental groups (Table 2).
Table 2. Productivity of turkey hens

\begin{tabular}{|c|c|c|c|c|c|c|}
\hline \multirow{2}{*}{ Indices } & \multicolumn{3}{|c|}{ Feeding groups } & \multirow{2}{*}{$P$} & \multirow{2}{*}{ SEM } & Significance \\
\hline & I II & III & IV & & & oil $E$ oil $\times E$ \\
\hline
\end{tabular}

Body weight/week of life, $\mathrm{kg}$

$\begin{array}{lllllllll}8 & 0.146 & 0.149 & 0.143 & 0.148 & 0.046 & 0.002 & \text { ns } & n s\end{array}$

$\begin{array}{llllllllll}14 & 0.325 & 0.333 & 0.319 & 0.330 & 0.055 & 0.001 & \text { ns ns ns }\end{array}$

$\begin{array}{llllllllll}35 & 1.60 & 1.62 & 1.71 & 1.75 & 0.061 & 0.007 & \text { ns } & n s & n s\end{array}$

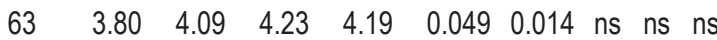

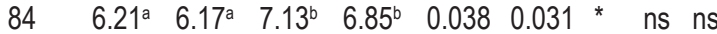

$112 \quad \begin{array}{lllllllll}9.28^{a} & 9.00^{a} & 10.11^{b} & 9.79^{b} & 0.041 & 0.068 & * & n s & n s\end{array}$

Body weight gain, $\mathrm{kg}$ per bird

$\begin{array}{llllllllll}8-14 & 0.179 & 0.184 & 0.176 & 0.182 & 0.074 & 0.001 & \text { ns ns ns }\end{array}$

$\begin{array}{lllllllll}15-35 & 1.28 & 1.29 & 1.39 & 1.42 & 0.066 & 0.009 & * & \text { ns ns }\end{array}$

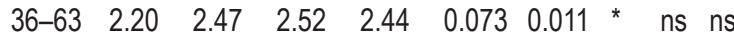

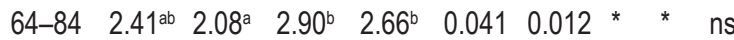

$\begin{array}{llllllll}85-112 & 3.07 & 2.83 & 2.98 & 2.94 & 0.055 & 0.003 & \text { ns ns ns }\end{array}$

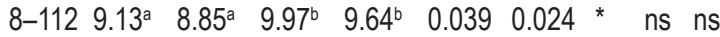

Feed intake, kg per bird per day

8-14 $0.040 \quad 0.036 \quad 0.036 \quad 0.041 \quad 0.066 \quad 0.001$ ns ns ns

$\begin{array}{llllllllll}15-35 & 0.095 & 0.091 & 0.084 & 0.087 & 0.073 & 0.002 & n s & n s & n s\end{array}$

$\begin{array}{lllllll}36-63 & 0.191^{\mathrm{b}} & 0.208^{\mathrm{b}} & 0.176^{\mathrm{a}} & 0.188^{\mathrm{ab}} 0.045 & 0.022 & *\end{array}$ ns ns

64-84 $0.290^{\mathrm{b}} 0.255^{\mathrm{a}} 0.280^{\mathrm{ab}} 0.267^{\mathrm{a}} 0.0490 .014$ ns * ns

$\begin{array}{lllllllll}85-112 & 0.320 & 0.333 & 0.301 & 0.308 & 0.067 & 0.003 & \text { ns ns ns }\end{array}$ $\begin{array}{lllllllll}8 & -112 & 0.216 & 0.216 & 0.202 & 0.206 & 0.058 & 0.001 & n s \\ n s & n s\end{array}$

Feed utilization, $\mathrm{kg} \cdot \mathrm{kg}^{-1}$

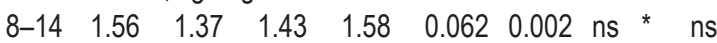

$\begin{array}{lllllllll}15-35 & 1.56 & 1.48 & 1.27 & 1.29 & 0.054 & 0.001 & * & \text { ns ns }\end{array}$

$\begin{array}{llllllll}36-63 & 2.43^{\mathrm{b}} & 2.36^{\mathrm{b}} & 1.95^{\mathrm{a}} & 2.16^{\mathrm{ab}} & 0.037 & 0.017 & *\end{array}$ * ns

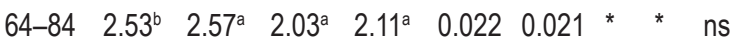

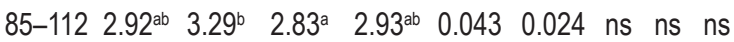

$\begin{array}{llllllll}8-112 & 2.48 & 2.56 & 2.13 & 2.24 & 0.059 & 0.002 & *\end{array}$ ns ns

PN 392.5 $369.0^{\text {a }} 497.9^{b} 458.7^{\text {b }} \quad$ * ns ns

a,b means with different superscripts within a row differ significantly at $P \leq 0.05$; ns - not significant; ${ }^{*} P \leq 0.05 ;{ }^{*} P \leq 0.01$; PN - production number

Table 3. Results of slaughter carcass analysis of turkey hens after 16 -week rearing period, \% body weight prior to slaughter

\begin{tabular}{|c|c|c|c|c|c|c|}
\hline \multirow{2}{*}{ Item } & \multicolumn{3}{|c|}{ Feeding groups } & \multirow{2}{*}{$P \quad$ SEM } & \multicolumn{2}{|c|}{ Significance } \\
\hline & I & II & III IV & & oil E & oil $\times E$ \\
\hline Dressing percentag & e83.8 & 83.6 & 85.084 .6 & 0.3090 .099 & ns ns & ns \\
\hline Breast muscle & 21.9 & 21.7 & 22.922 .8 & 0.2810 .156 & ** ns & ns \\
\hline Femoral muscle & $8.73^{\mathrm{ab}}$ & $8.48^{a}$ & $9.05^{b} 8.57^{a t}$ & 0.0840 .071 & $* \quad * *$ & ns \\
\hline Shank muscle & $6.85^{\mathrm{a}}$ & $6.50^{\mathrm{a}}$ & $7.31^{\mathrm{b}} 6.86^{\mathrm{ab}}$ & 0.0260 .066 & $* * * *$ & ns \\
\hline Liver & 1.44 & 1.33 & 31.531 .58 & 0.0880 .023 & $3^{* *} \mathrm{nS}$ & ns \\
\hline Gizzard & 1.26 & 1.28 & 1.231 .27 & 0.0750 .014 & ns ns & ns \\
\hline Heart & 0.30 & 0.30 & 0.310 .33 & 0.0910 .004 & ns ns & ns \\
\hline Abdominal fat & $0.53^{\mathrm{ab}}$ & $0.42^{b}$ & $0.60^{a} 0.59^{a}$ & 0.0330 .015 & ${ }^{* * * *}$ & * \\
\hline
\end{tabular}

The introduction of linseed oil into the diet was found to significantly affect the results of carcass analysis. It contributed to an increase in the weight of the breast muscle, femoral muscle, shank muscle and liver (Table 3). Compared with group II, the adipose fat content was about $40 \%$ higher $(P \leq 0.05)$ in turkey hens receiving linseed oil (III and IV). In the group of turkey hens fed the feed mixture with 
Table 4. Haematological parameters in blood of turkey hens

\begin{tabular}{|c|c|c|c|c|c|c|c|}
\hline \multirow{2}{*}{ Item } & \multicolumn{4}{|c|}{ Feeding groups } & \multirow{2}{*}{$P$} & \multirow{2}{*}{ SEM } & \multirow{2}{*}{$\begin{array}{l}\text { Significance } \\
\text { oil } E \text { oil } \times E\end{array}$} \\
\hline & I & II & III & IV & & & \\
\hline$-\mathrm{tt}, \mathrm{I} \cdot \mathrm{I}^{-1}$ & $0.25^{\mathrm{a}}$ & $0.31^{b c}$ & $0.28^{a b}$ & $0.32^{c}$ & 0.023 & 0.006 & $\mathrm{~ns}$ ** ns \\
\hline $\mathrm{Hb}, \mathrm{g} \cdot \mathrm{I}^{-1}$ & $7.26^{\mathrm{a}}$ & $10.73^{c}$ & $8.38^{a b}$ & $9.43^{b}$ & 0.038 & 0.229 & $\mathrm{~ns} * * * *$ \\
\hline $\mathrm{RBC}, 10^{12}$ & $2.27^{\mathrm{a}}$ & $2.20^{\mathrm{a}}$ & $2.39^{b}$ & $2.39^{b}$ & 0.026 & 0.016 & ** ns ns \\
\hline
\end{tabular}

$\mathrm{Ht}$ - haematocrit, $\mathrm{Hb}$ - haemoglobin, $\mathrm{RBC}$ - erythrocytes; a,b,c means with different superscripts within a row differ significantly at $P \leq 0.05$; ns - not significant; ${ }^{*} P \leq 0.05 ;{ }^{* *} P \leq 0.01$

Table 5. Biochemical parameters in blood plasma of turkey hens

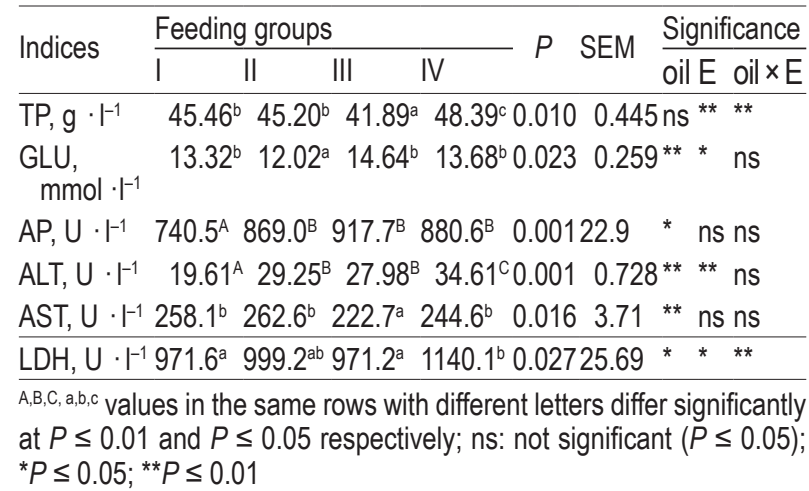

Table 6. Mineral content in blood plasma of turkey hens

\begin{tabular}{llllll}
\hline Item & \multicolumn{2}{l}{ Feeding groups } & & SEM & Significance \\
\cline { 2 - 5 } & I III E oil $\times \mathrm{E}$ & III & IV & &
\end{tabular}

\begin{tabular}{lllllll}
\hline $\mathrm{P}, \mathrm{mmol} \cdot \mathrm{l}^{-1}$ & 2.00 & 1.98 & 1.97 & 1.98 & 0.66 & $0.028 \mathrm{~ns} n \mathrm{~ns}$
\end{tabular}

$\mathrm{Ca}, \mathrm{mmol} \cdot \mathrm{l}^{-1} \quad 2.69^{\mathrm{ab}} 2.91^{\mathrm{b}} \quad 2.51^{\mathrm{a}} 2.70^{\mathrm{ab}} 0.0390 .042^{*}$ * ns

$\mathrm{Mg}, \mathrm{mmol} \cdot \mathrm{l}^{-1} \quad 0.80^{\mathrm{b}} \quad 0.69^{\mathrm{a}} \quad 0.94^{\mathrm{c}} \quad 0.97^{\mathrm{c}} 0.042 \quad 0.018$ ** $\mathrm{ns}^{*}$ *

$\mathrm{Cu}, \mu \mathrm{mol} \cdot \mathrm{l}^{-1} 21.20^{\mathrm{a}} 25.77^{\mathrm{b}} 25.33^{\mathrm{b}} 28.21^{\mathrm{c}} 0.0340 .460^{* *}$ ** ns

$\mathrm{Zn}, \mu \mathrm{mol} \cdot l^{-1} 27.23^{\mathrm{b}} 27.10^{\mathrm{b}} 23.24^{\mathrm{a}} 26.05^{\mathrm{b}} 0.0470 .448^{* *}$ ns ns

$\mathrm{Fe}, \mu \mathrm{mol} \cdot l^{-1} 40.09^{\mathrm{A}} 48.14^{\mathrm{B}} 46.68^{\mathrm{B}} 53.08^{\mathrm{C}} 0.0010 .742^{* *}{ }^{* *} \mathrm{~ns}$

$\mathrm{A}, \mathrm{B}, \mathrm{C}, \mathrm{a}, \mathrm{b}, \mathrm{c}$ values in the same rows with different letters differ significantly at $P \leq 0.01$ and $P \leq 0.05$ respectively; ns: not significant $(P \leq 0.05)$; ${ }^{*} P \leq 0.05 ;{ }^{* *} P \leq 0.01$

dl- $\alpha$-tocopherol acetate (I and III), the weight of the femoral and shank muscles was significantly higher $(P \leq 0.05)$ than in the birds from groups II and IV. The addition of RRR d- $\alpha$-tocopherol was also found to increase the weight $(P \leq 0.05)$ of the femoral muscle, shank muscle and abdominal fat (Table 3).

The addition of linseed oil to the feed mixture led to an increase in the erythrocyte count, while added RRR-d- $\alpha$-tocopherol resulted in significantly higher mean erythrocyte ( $\mathrm{Ht}$ and $\mathrm{Hb}$ ) indices (Table 4).

The mean content of total protein in the blood plasma of the birds was lower in group III, whereas that of glucose was lower in group I in comparison with the other experimental groups $(P \leq 0.05$; Table 5). The statistical analysis demonstrates that the addition of vitamins had a stimulating effect on $\mathrm{TP}$ concentration in the blood of the turkey hens, and that the type of oil administered in feed mixtures affected the GLU level in the blood plasma.
Transaminases (ALT, AST) are enzymes strongly linked with protein metabolism. In the course of the experiment, their activity was subject to fluctuations (Table 5). The addition of linseed oil caused a reduction in plasma AST activity and an increase in the activity of AP, ALT and LDH. The case of LDH activity was slightly different, as significantly lower values were noted in the birds from groups receiving the natural form of vitamin E (RRR-d- $\alpha$ tocopherol).

The addition of different forms of fat (soyabean or linseed oil) significantly affected the concentration of mineral nutrients, with the exception of phosphorus. The addition of linseed oil caused an increase $(P \leq 0.05)$ in the concentration of $\mathrm{Mg}, \mathrm{Cu}$ and $\mathrm{Fe}$ in the blood plasma of the turkey hens, while the addition of the natural form of vitamin E (RRR$\mathrm{d}-\alpha$-tocopherol) significantly increased the content of $\mathrm{Ca}, \mathrm{Cu}$ and $\mathrm{Fe}$ (Table 6).

\section{Discussion}

The study showed that the use of linseed oil as a source of fat in feed for turkeys improved production results, expressed as an increase in final body weight and higher production numbers $(\mathrm{PN})$. Replacing animal fats with vegetable (linseed, sunflower, or soyabean) or fish oils in feed mixtures for poultry effectively changes the profile of fatty acids of the $\omega-3$ and $\omega-6$ families, which may improve production performance and also affect the health status of animals (Chashnidel et al., 2010). Beneficial production effects of administration of linseed in poultry feeding have been demonstrated by Nam et al. (1997).

Much attention is, therefore, paid in practice to linseed oil, which may be used effectively in animal feeding and does not contain antinutrients (Eiben et al., 2010). It contains significant quantities of $\alpha$-linolenic acid, which is the native long-chain form of $\omega-3$ PUFA and may in part (about $10 \%-30 \%$ ) be transformed in the body to EPA, DPA and DHA (Weill et al., 2002). The more favourable production performance achieved in the experiment is likely to be due to better availability of linseed oil compared with soyabean oil in birds, which was also shown in a study by Blanch et al. (1996). The improvement in production performance may also be affected by the ratios of C18:2 (LA; $\omega-6)$ and C18:3 (LNA; $\omega$-3) fatty acids in the oils, which - as reported by Hassan et al., (2011) - are 1:4 in linseed oil and 9:1 in soyabean oil. The effects of using various fat sources (soyabean oil, rapeseed oil, a mixture of vegetable oils) in poultry feeding were also discussed by 
Zollitsch et al. (1997) and Kessler et al. (2009). According to Jankowski et al. (2012), linseed oil used as an alternative to rapeseed oil increases the final body weight in turkeys.

There are also some studies indicating that the use of various fat sources may additionally affect the results of carcass analysis. A study by Newman et al. (2002) demonstrated a decrease in the content of adipose fat in birds administered feed mixtures with the addition of sunflower oil, compared with those receiving fish oil or tallow as a source of fat. Similar dependencies were observed by Ferrini et al. (2010) in an experiment with broilers receiving feed mixtures with linseed oil. Likewise, in our study, an increased content of adipose fat was observed in the turkey hens receiving linseed oil compared with the birds fed the feed mixture with soyabean oil. A significantly higher percentage content of breast, thigh and shank muscles was also noted in the birds receiving linseed oil.

The addition of the natural form of tocopherol significantly increased the weight of the legs and abdominal fat, in contrast to the results of Malczyk (2001), who studied vegetable oils and dl- $\alpha$-tocopherol added at different levels to chicken diets and did not find any influence on dressing percentage or breast and leg muscle content. The dissection findings are difficult to discuss due to the lack of similar data concerning turkeys in the available literature. However, the research data obtained are within the range of values reported in earlier studies on turkeys (Czech et al., 2010).

A significant element in evaluating the effectiveness of feed additives in animal feeding is the course of metabolic processes, which is manifested by changes in haematological and biochemical blood markers. Stimulating immune processes by adding fatty acids reduces susceptibility to the development of inflammatory processes, which in turn is reflected in erythropoiesis (Hassan et al., 2011). This was also confirmed in the present study. In the birds receiving linseed oil, RBC indices were significantly higher than in the group administered the feed mixture with soyabean oil. The addition of the natural form of vitamin E also significantly increased the erythrocyte indices, i.e. $\mathrm{Ht}$ and $\mathrm{Hb}$. Similar results, especially in the case of young birds, were obtained by Hassan et al. (2011). The addition of linseed oil also caused an increase in the concentration of minerals in the blood plasma of the birds, particularly of those closely linked to erythropoiesis $(\mathrm{Cu}, \mathrm{Fe})$. Similar correlations were noted in the birds receiving the natural form of vitamin E (RRR-d- $\alpha$-tocopherol). The natural $d-\alpha$-tocopherol occurring in products of plant origin or deposited in animal tissues is almost twice as active as the synthetic form of tocopherol (Koreleski and Świątkiewicz, 2008).

A reduction in the amount of vitamin $\mathrm{E}$ in animal feed rations may diminish the antioxidant capability of cell membranes (particularly in erythrocytes), which is conducive to membrane lipid peroxidation and thus reduces their fluidity and increases their permeability (Augustyniak and Skrzydlewska, 2004). Disturbances in the functioning of cellular membranes primarily affect the penetrability of nutrients and minerals. Addition of RRR-d- $\alpha-$ tocopherol to the feed mixtures for turkeys caused a significant increase in the content of calcium, and, in particular, of iron and copper in the blood plasma of the birds. These elements play an active role in erythropoiesis and antioxidation, which are closely linked to the presence of endogenous proteins that bind metal ions (albumin and ceruloplasmin bind copper (II) ions and ferritin binds iron ions), and suppress the intensity of free radical reactions (Perry et al., 2002). The increase in the $\mathrm{Fe}^{+2}$ and $\mathrm{Cu}^{+2}$ contents corresponded with an increase in total protein in the blood plasma, which was significantly higher in the turkey hens receiving the feed mixture with linseed oil and RRR-d- $\alpha$-tocopherol. Such a relation was not observed by Hassan et al. (2011). Transaminases (ALT, AST) are enzymes closely linked with protein metabolism. Over the experimental period their activity was subject to fluctuations. In a study by Hassan et al. (2011) with 18-week-old chickens fed diets containing linseed oil, the activity of both AST and ALT was significantly lower than in the birds receiving diets with a mixture of vegetable oils, but comparable to those administered a diet with soyabean oil. A study by Jankowski et al. (2012), however, indicates that linseed oil used as an alternative to rapeseed oil has no effect on the blood biochemical parameters of turkeys.

\section{Conclusions}

The use of linseed oil improve production effects and the results of carcass analysis in turkey hens. It may also contribute to stimulation of erythropoiesis. It should be emphasized, however, that it may overburden the organism, as indicated by the increased liver enzyme activity.

It is be possible to use the natural form of tocopherol in diets rich in linoleic and linolenic acid (soyabean/linseed oil) without detrimental effect on metabolic status and rearing performance of turkey hens. It should be emphasized, however, that 
the commonly used tocopherol acetate, despite the higher dosage, is cheaper and has similar effects. Thus, from an economic point of view, the use of linseed oil with the synthetic form of vitamin $E$ is worth recommending.

\section{Acknowledgements}

The study was supported by the Ministry of Science and Higher Education, Project No. N N311 633738.

\section{References}

Augustyniak A., Skrzydlewska E., 2004. Antioxidative abilities during aging. Post. Hig. Med. Dosw. 58, 194-201 (online)

Blanch A., Barroeta A.C., Baucells M.D., Serrano X., Puchal F., 1996. Utilization of different fats and oils by adult chickens as a source of energy, lipids and fatty acids. Anim. Feed Sci. Tech. $61,335-342$

Chashnidel Y., Moravej H., Towhidi A., Asadi F., Zeinodini S., 2010. Influence of different levels of $n-3$ supplemented (fish oil) diet on performance, carcass quality and fat status in broilers. Afr. J. Biotechnol. 9, 687-691

Cortinas L., Barroeta A., Galobart J., Jensen K., 2004. Distribution of a-tocopherol stereoisomers in liver and thigh of chickens. Brit. J. Nutr. 92, 295-301

Czech A., Ognik K., Chachaj R., 2010. Efficiency of synthetic antioxidants mixture additive in turkey hens diet. Ann. UMCS, Sect. EE 4, 1-7

Eiben Cs., Végi B., Virág Gy., Gódor-Surmann K., Maró A., Odermatt M., Zsédely E., Tóth T., Schmidt J., 2010. Effect of different dietary ratios of sunflower and linseed oils on growth and carcass traits of rabbits. Livest. Sci. 131, 15-22

Euribrid B.V., 1994, Technical Information for Hybro Broilers, Euribrid Poultry Breeding Farm, Boxmeer (The Netherlands), pp.22

Feldman B., Zinki J., Jain N., 2000. Schalm's Veterinary Haematology. Lippincott and Wilkins. Philadelphia (USA)

Ferrini G., Manzanilla E.G., Menoyo D., Esteve-Garcia E., Baucells M.D., Barroeta A.C., 2010. Effects of dietary n-3 fatty acids in fat metabolism and thyroid hormone levels when compared to dietary saturated fatty acids in chickens. Livest. Sci. 131, 287-291

Hassan M.S.H., Nadia L., Radwan A.M., Khalek A., Abd El-Samad M.H., 2011. Effect of different dietary linoleic acid to linolenic acid ratios on some productive, immunological and physiological traits of Dandarawy chicks. Egypt. Poultry Sci. J. 31 (online)

Jankowski J., Zduńczyk P., Mikulski D., Juśkiewicz J., Mikulska M., Zduńczyk Z., 2012. Effects of dietary soyabean, rapeseed and linseed oils on performance, slaughter yield and fattyacid profile of breast meat in turkeys J. Anim. Feed Sci. 21, 143-156
Kania M., Michalak M., Gogolewski M., Hoffmann A., 2004. Antioxidative potential of substances contained in cold pressed soybean oil and after each phase of refining process. Acta Sci. Pol. Technol. Aliment. 3, 113-121

Kessler A.M., Lubisco D.S., Vieira M.M., Ribeiro A.M.L., Penz Jr. A.M., 2009. Fatty-acid composition of free-choice starter broiler diets. Rev. Bras. Ciência Avícola 11, 31-38

Koreleski J., Świątkiewicz S., 2008. Enrichment of vitamin E in breast meat by adding tocopheryl acetate to the feed of broiler chickens. Med. weter. 64, 3348-350

Kouba M., Mourot J., 2011. A review of nutritional effects on fat composition of animal products with special emphasis on $\mathrm{n}-3$ polyunsaturated fatty acids. Biochimie 93, 13-17

Mahan D.C., Kim Y.Y., Stuart R.L., 2000. Effect of vitamin E sources (RRR-or all-rac-a-tocopheryl acetate) and levels on sow reproductive performance, serum, tissue, and milk a-tocopherol contents over a five-parity period, and the effects on the progeny. J. Anim. Sci. 78, 110-119

Malczyk E., 2001. Evaluation of quality features and meats of chickens of broilers fed fodder concentrated into vegetable oils and alfa-tokoferol (in Polish). Zesz. nauk. Akad. Rol. Wrockaw, Technol. Żyw. 14 (407), 23-39

Nam K.T., Leea H.A., Minb B.S., Kanga C.W., 1997. Influence of dietary supplementation with linseed and vitamin $E$ on fatty acids, tocopherol and lipid per oxidation in muscles of broiler chicks. Anim. Feed Sci. Tech. 66, 149-158

Newman R.E., Bryden W.L., Fleck E., Ashes J.R., Buttemer W.A., Storlien L.H., Downing J.A., 2002. Dietary n-3 and n-6 fatty acids alter avian metabolism: metabolism and abdominal fat deposition. Brit. J. Nutr. 88, 11-18

NRC, 1994. Nutrient Requirements of Poultry. $9^{\text {th }}$ revised Edition. Washington, DC

Ognik K., Czech A., 2014. Effect of applying soybean, linseed oil and different forms of tocopherol on the redox and immune profiles of turkey hens. S. Afr. J. Anim. Sci. http://dx.doi.org/10.4314/ sajas.v44i1

Perry G., Nunomura A., Hirai K., Zhu X., Perez M., Avila J., Castellani R.J., Atwood C.S., Aliev G., Sayre L.M., Takeda A., Smith M.A., 2002. Is oxidative damage the fundamental pathogenic mechanism of Alzheimer's and other neurodegenerative diseases? Free Radical Biol. Med. 33, 1475-1479

Weill P., Schmitt B., Chesneau G., Daniel N., Safraou F., Legrand P., 2002. Effects of introducing linseed in livestock diet on blood fatty acid composition of consumers of animal products. Ann. Nutr. Metab. 46, 182-91

Yu L.L., Wang R.L., Zhang Y.Z., Kleemann D.O., Zhu X.P., Jia Z.H., 2008. Effects of selenium supplementation on polyunsaturated fatty acid concentrations and antioxidant status in plasma and liver of lambs fed linseed oil or sunflower oil diets. Anim. Feed Sci. Tech. 140, 39-51

Zollitsch W., Knaus W., Aichinger F., Lettner F., 1997. Effects of different dietary fat sources on performance and carcass characteristics of broilers. Anim. Feed Sci. Tech. 66, 63-73 